\title{
Woncheuk 圓測 on Bimba 本質 and Pratibimba 影像 in his Commentary on the Samdhinirmocana-sütra
}

\author{
A. Charles Muller
}

\section{Background}

In its standard meaning in Yogâcāra works, bimba, translated into Chinese as 本質 (C. běnzhi; J. honzetsu), refers to the bare form of an object of sense or of thought, before it has received any interpretation, overlay, or categorization through the cognitive process. Its counterpart is pratibimba 影像 (C. y̌ngxiàng; J. yōzō), which is a reflected "image"1) of the bimba, that which we actually "see" on the surface of consciousness, having been interpreted and transformed by the cognitive process. There was, during the early reception in the West of Weishi documents, a widely-promulgated misunderstanding of the term honzetsu, wherein it was often rendered into English as "archetypes," as seen, for example, in Daito shuppansha's Japanese-English Buddhist Dictionary (Revised Edition, 1991) which contains the following entry:

Honzetsu 本質 Archetype. This term is used by the Hossō Sect to indicate the true substance a phenomenon of which we perceive only the image. Thus, when we see a tree, we don't see the tree itself (which is the honzetsu) but the image of the tree which is reflected in the sōbun 相分 (cf. shibun) division of our consciousness.

This is partly right, in the sense that we do only see an image-of whatever it is that is there. But it is clear that the authors of this dictionary held some combination of misunderstanding of the meaning of archetypes, ${ }^{2)}$ or of the function of bijja ("seeds") in the alayavijūāna. After all, these "seeds," while producing phenomena, are themselves continually being impregnated and reproduced, bringing about a complex condition of incessant combination of change that includes continuity of sameness. We will return to consider possible causes for this kind of interpretation below. 


\section{Development of the Bimba-Pratibimba Framework in the Yogâcāra Texts}

Most of the detailed explanations and applications of the bimba-pratibimba pair-especially those that have informed the canonical definitions contained in East Asian Buddhist lexicons-are derived from Kuiji's 窥基（632-682） commentaries: especially those on the Yogâcārabhīmi-śāstra, ${ }^{3)}$ and his detailed elaborations of the Cheng weishi lun. ${ }^{4)}$ These works contain extensive discussions of 本質 and 影像 from various perspectives. Most importantly, he often treats these notions in the context of their application within the everyday waking consciousness, rather than only in the context of yogic trances. We will briefly look at some of Kuiji's contributions below.

The initial appearance of the pair, however, occurs within a well-known passage that is shared almost verbatim between the Samdhinirmocana-sūtra and the Yogâcârabhūmi-śāstra. ${ }^{5)}$ In this initial reference to the pair of bimba and pratibimba, the meanings of, and relationship between the two terms are explained only in a very minimal way, leaving the meaning of bimba itself almost fully open to speculation. It is only in later Yogâcāra works (mainly commentarial works) that the concepts come to be defined as we know them today. ${ }^{6)}$ Also, the discussion in this passage of the Samdhinirmocana-sütra deals strictly with the way images appear on the surface of the consciousness of yogins who are practicing śamatha and vipaśyana meditation. It does not discuss the case of material objects impinging on the consciousness of regular people in daily waking activity.

\section{Some Standard Interpretations Provided by Kuiji}

The pair of bimba and pratibimba became an important component of Kuiji's account of the cognitive experience in a numerous ways, and it is primarily in his works that detailed explanations first appear regarding the meaning of bimba. One of the descriptions provided by Kuiji, wherein bimba are explained as being "produced from seeds" (in the alayavijñā$n a)^{7)}$ is likely the source based on which some early Western scholars ended up connecting bimba with the Western notion of archetypes. One would guess that such scholars had taken $b \bar{l} j a$ to be something akin Platonic forms, or some other kind of original conceptual template which serves as the model for generating like appearances. However, since Yogâcāric bijja are understood to be continually in flux, created each instant as a combination of a wide range of factors, a reified interpretation such as that of "archetype" misses the point. 
Kuiji raises the topic of bimba and pratibimba in his commentaries in a variety of contexts, many of them which deliberately problematize their relationship with each other, as well as their relationship with the four elements. Their role is examined in the function of a variety of mental states, both yogic and conventional, both human and non-human. ${ }^{8)}$ There are cases where bimba are said to be produced from seeds, and cases where they are not. On one hand, bimba are seen to be necessary as objective bases, as without them, pratibimba would have no application whatsoever. ${ }^{9)}$ On the other hand, for divine beings, the reliance on bimba to cognize objects is not necessary. ${ }^{10)}$ Nor are they always required in the cognition of those who are exercising supernatural powers. ${ }^{11)}$

Kuiji's best known usage of 本質 and 影像 is seen in his analysis of the objects of cognition into three general types, known as the 三類境 (C. sānlèi jing; J. sanrui kyō). ${ }^{12)}$ The pair is also discussed making the distinction of 影像 being the "perceptual object directly perceived by the consciousness” 親所緣 (C. qin suǒyuán; J. shin shoen), whereas bimbathe raw substance 本質, is not known directly, and is called the "indirectly perceived object" 柾所緣 (C. suǒyuán; J. so shoen). These two aspects taken together are understood to constitute the "seen part" 相分 (C. xiāng fên; J. sōbun) of consciousness, being the "raw substance seen part" 本質相分 (C. běnzh xiàngfên; J. honzetsu sōbun) and the "reflected image seen part” 影像相分 (C. yìngxiàng xiàngfēn; J. yōzō sōbun). There are a number of other ways that the pair fits into Kuiji's articulations of cognitive function, but let us now proceed to the discussion of these concepts in Woncheuk.

\section{Bimba 本質 and Pratibimba 影像 in Woncheuk}

While the discussion of this pair of concepts in East Asian Buddhist Weishi scholarship has been dominated by Kuiji's extensive and detailed work, he is not the only one who saw the seminal importance of these categories for their application in various epistemological and hermeneutic situations, as Woncheuk 圓測 (613-696), for one, also paid a fair amount of attention to this topic. While there does not seem to be anything in Woncheuk's writings on this topic that directly disagrees with the interpretations of Kuiji, nonetheless, as in his other writings, Woncheuk tends to be an original thinker, and thus utilizes the pair in different contexts, and draws on different sources than famous colleague and rival. In his commentary to the Samdhinirmocana-sūtra, ${ }^{13)}$ Woncheuk presents two major discussions involving bimba-pratibimba: one is in connection with the explication of the famous paral- 
lel passage found in the Samdhinirmocana-sūtra and Yogâcārabhümi-śāstra, wherein pratibimba are the objects of śamatha and vipaśyana meditation, and where the precise meaning of bimba is somewhat problematic. The other comes midway through the introductory portion of the commentary, where he is setting up his hermeneutic framework for the commentary through the discussion of such matters as the title of the sūtra, the possibility for teaching, and so forth. Here, we are introduced to a new type of application of bimba and pratibimba: an attempt to employ them in a situation not related to visual objects, as is almost always the case, but rather to the explanation of the "essence of the teaching" 宗體 (C. zōngtí; J. shütai). While the discussion of bimba-pratibimba in the sūtra passage on samatha and vipaśyana is extremely valuable for understanding these concepts, due to space constraints, we will here limit our discussion to his usage of the concepts in his introduction, since this is of greater interest in terms of showing Woncheuk's creativity.

\section{Applying Bimba and Pratibimba in the Identification of the Essence of the Teaching 宗體}

If this model of the bimba-pratibimba pair is going to be applied as a way of distinguishing stages or modes in the process of the apprehension of perceptual objects, how should it work in the case of the other senses or perceptions, and what kind of vocabulary should be used? In most cases, this question may not so readily arise, since the visual model is so predominant. Both bimba and pratibimba fundamentally mean "image." And all of the explanations and metaphors are done through visual imagery, with the mirror and its reflections being the preeminent trope. But what about sound, odor, taste, and tactile sensation? How do we describe these, or try to make them work through the same paradigm?

Here, we can see some wisdom in Xuanzang's choice of the compound word of 本質 to render bimba, which, unlike its Sanskrit counterpart, has no reference to imagery, but literally means something like "raw substance." We can also understand, perhaps, that finding a term that functioned with equal neutrality among the sensory fields to refer to the "processed" aspect of sensation/perception would be much more challenging, and perhaps it is for that reason that he opted for the readily understandable equivalent of "reflected image" 影像 for pratibimba. This kind of awareness, however, cannot but problematize our attempts at English translation, if, for example, we needed to find a word that can also adequately express the same kind of modality as "reflected image" for the processed form of sound or 
other sensory and perceptual objects. ${ }^{14)}$

Woncheuk's discussion of 本質/影像 in the context of the "Buddha's teaching" comes in the middle portion of his introduction to his commentary, where he is establishing his hermeneutical structure. In the section on the explanation of the Essence of the Teaching, Woncheuk enters into an extensive philosophical inquiry attempting to identify exactly what the "essence" of the teaching is. This leads him to a discussion of the "three aggregations" of words, 名身 (C. míngshēn; J. myōshin), phrases 句身 (C. jüshēn; J. kushin), and syllables 文身 (C. wén shēn; J. monshin), which further leads to the discussion of the relation of these three to a fourth element-sound 音聲 (C. yīnshēng; J. onshō) -and further, which of these is to be considered as the "essence" of the teaching. Since he enriches the argument by presenting a range of interpretations based on the viewpoints of various schools of Indian philosophy - both Buddhist and non-Buddhist - the discussion gets rather complicated, as some of the more prominent early Indian philosophical texts had much to say about the metaphysical status of sound. In the final analysis, however, in the case of the Buddhist scriptures, Woncheuk takes "words" rather than "sound" as the essence, citing the opinion of his master Xuanzang as the final authority.

This discussion, which consists of a comparative analysis of the positions of various philosophers on the existence or not of "raw substance" and "representations" in the context of the previously discussed four phenomena of sound 音䠛 and the aggregations of words 名 身, phrases 句身, and syllables 文身, starts off with:

These four dharmas, according to the Tathāgata's own explanation, are called 'raw substance.' The listener's transformation of these through cognition is called 'representation.' The distinction between the existence and non-existence of these raw substances and representations is broadly distinguished into four kinds of tenets by the various traditions. ${ }^{15)}$

This is a novel and interesting application of the concept of bimba/pratibimba that is somewhat different from the type of explanation we find in Kuiji's writings. Yet on the other hand, it might tell us something about the way that Woncheuk, and perhaps the other Buddhist thinkers of his period understood the notions of sound, words, phonemes, etc.

For it seems that if we were presented with these four seminal Indian Abhidharmic-Yogâcāric phenomena of words, phrases, phonemes, and sound, our first reaction would be to regard sound itself as a bimba, and the other three as pratibimba. But does taking all four as bimba mean that Woncheuk sees words, phrases, and phonemes uniformly as pre-con- 
ceptual entities? Such an interpretation is not impossible. It would mean that he understands that our thinking consciousness apprehends all of these things to a certain level in these distinct yet "unrepresented" units, and afterwards reflects them as meaningful units. It may also be the case that Woncheuk is intentionally using the notion of bimba/pratibim$b a$ here in a looser sense as a hermeneutical device.

The four hermeneutic positions that Woncheuk sets up to distinguish the approaches of prior philosophers are those of:

1. the existence of raw substance and non-existence of representations 有本無影;

2. the existence of representations and non-existence of raw substances 有影無本;

3. the existence of both raw substances and representations 本影俱有;

4. the existence of neither raw substances nor representations 本影俱無.

In a format very close to that which he uses later on in his exegesis of the well-known bimba-pratibimba discussion in the context of meditation, he summarizes all of the arguments of the philosophers who support each of the four positions, and then wraps up the discussion (as he often does in his commentary), citing Xuanzang as the final authority (and on this occasion, Dharmapāla as well). This discussion can be summarized as follows:

1. Existence of Raw Substance and the Non-Existence of Reflections 有本無影一Woncheuk says that there are three philosophical streams that support this view. (1) That of the Sarvâstivādins, for whom all buddha-voices are only contaminated. Some also say that words, etc., are definitely of morally indeterminate karmic character. This kind of point is elaborated in detail in the Mahāvibhāșā-siâstra. (2) The position taken up by the Mahāsāṃghika, Ekavyāvahārika 一說部, Lokôttaravādins 說出世部, Kukkutịa 雞济部, and so forth, who say that all world-honored buddhas are transmundane, lacking contaminated dharmas. The words of the tathăgatas turn the wheel of the dharma; the buddhas, in a single voice, explain all the teachings. (3) The position of the Bahuśrutīya 多聞部說, who take the "five notes"16) of the Buddhas teaching to be transmundane. All other kinds of voice are the mundane teachings. Woncheuk comments that the reason all these schools have this misunderstanding is because they don't get the teaching of Consciousness-only.

2. Existence of Reflections and Non-Existence of Raw Substances 有影無本一The second tenet is that of the existence of representations and the non-existence of raw substances. The Nāgasena 那伽犀那 say that the Buddha-realization consists only of thus- 
（204）Woncheuk 圓測 on Bimba 本質 and Pratibimba 影像 in his Commentary on the Samdhinirmocana-sütra (A. C. MuLLER)

ness and the thusness-cognition, and does not involve coarse attributes such as form, sound, and so forth. According to Woncheuk, Sthiramati 堅慧論師 and Vajrasena 金 剛軍 also support this interpretation.

3. Existence of Both Raw Substances and Reflections 本影俱有一Such scholars as Candragupta 月藏 and Bandhuprabha 親光 say that all tathāgatas are endowed with such attributes as the form and sound of the three bodies. The Suvarna-prabhäsôttamasūtra says: "The Tathāgata is able to turn three kinds of dharma wheels-the turning [wheel], illuminating [wheel], and the maintaining [wheel] ${ }^{, 17)}$ This kind of teaching shows that what is witnessed is not the same. In some cases the listener's consciousness transforms [what is heard] to appear like another teaching. Hence they know that raw substance and representations both exist.

4. Existence of Neither Raw Substances Nor Reflections 本影俱無—Coming from the point of view of the absolute truth, Bhāvaviveka 淸辯 advocates the emptiness of the natures of all dharmas. Some assume that Dharmapāla 護法 took the stance of the ultimate truth when he said that in the Tathāgata's holy teaching, raw substances and representations are both non-existent. This is because in the ultimate truth, there are no words and so forth.

Finally, he wraps up with:

Although the positions are categorized into four like this, the school of the Trepitaka of the Great Tang (Xuanzang) and of Dharmapāla have two interpretations. One is from the perspective the teaching of reality, in which there is only raw substance and no representations; this is because raw substance is that which is properly explained by the Tathāgata. In the second theory both are properly included; this is because both arise according to the power of the Tathāgata's teaching. (HBJ $1.126 \mathrm{c} 12-15)$

From here, this discussion segues into another fascinating discussion, that also deals with the elements of word, phonemes, sound, etc. - the discussion of the possibility of the holy teaching from an entirely different perspective: the question of how to deal with the statement appearing in the Lankk̂vatāra-sūtra and elsewhere that says: "During the time between the night I attained supreme perfect enlightenment, until the night I entered final nirvāna, I did not explain a single thing. Furthermore, it did not explain it in the past, and will not explain it in the future. Not-explaining is the Buddha's explanation." (T 670.16.498c17-19) That, however, needs to be left as the topic for another paper. 
1) We use the word "image" here with caution, because a full extension of the notion to all sensory functions means that it has to be more than simply "image," as will be noted below.

2 ) Merriam-Webster: (1) the original pattern or model of which all things of the same type are representations or copies. (2) An inherited idea or mode of thought in the psychology of C. G. Jung that is derived from the experience of the race and is present in the unconscious of the individual. Japanese: アーキタイプ (典型, 原型, 元型) スイスの心理学者カール・ユング の用いた心理学用語. 人間の心の深層にあって遺伝的に伝わり，集合的無意識を作り 上げている心像の基本的な型。（Web ALC Dictionary: http://www.alc.co.jp/）

3 ) The Yuqielun ji 瑜伽論記 ( T 1828).

4) Primarily in his Cheng weishi lun shuji 成唯識論述記 (T 1830), and his Cheng weishi lun zhangzhong shuyao 成唯識論掌中樞要（T 1831）.

5 ) Dealt with most recently in Japanese scholarship by KATŌ Kojirō, who analyzed these passages, yielding the convincing report that they are not quite as identical in their full connotation as has been traditionally assumed. See KATŌ Kōjirō, 加藤弘二郎. “Pratibimba in the Context of Vijñaptimātra Theory: A Comparative Study of the Śrāvakabhūmi and the Samdhinirmocana sūtra (Chap.VI)「唯識」という文脈で語られる影像”. Indo tetsugaku bukkyō kenky $\bar{u}$, vol. 9, pp. 53-65.

6 ) This situation is of course true for many other seminal concepts that are held up as Yogâcāra paradigms, as I have recently tried to demonstrate in my forthcoming article that deals with the development of the notion of the two hindrances, entitled "The Contribution of the Yogâāab$h \bar{u} m i$ to the System of the Two Hindrances," in an edited volume in progress.

7 ) For example, 玄師述三藏云。從賴耶識中名言種子生本質相。（T 1828.42.744c26-27); 熏成種子生本質故.（T 1831.43.620b16）

8 ) See, for example, T 1831.43.632b3-7. 勝定果色大種造不。如對法第一末疏. 雖有五文 說造不同. 說先變爲大種後造色生. 竝同繫等交者. 有義此說依欲色二界地定果色. 以 有所依身故。無色界定果色. 從本質大種造. 定中無大種. 無所依身.

9 ) 若約本質. 或無本質法一切名等. 同緣一境故. 與事等不同. 若影像相相似名等. 何 事一種．無分別智緣如無影不可相似．不同一．故知有本質者．影像名相似．本質名同 一。若無本質者。有爲緣相似名同一。無爲緣境一名同一。此握實緣故不相違（T 1831.43.634a6-11)

10）其上天眼耳見聞下色聲不託本質.（T 1831.43.632a26）

11）若定通力所變五應. 非必有本質如生上界緣下界地色. 或身在下起天眼耳緣上地色 等又解異熟之心緣境浮淺。非要藉本質。（T 1831.43.648c20-23）

12) These are: (1) 性境 (C. xingjing; J. shōkyō) Objects as they are in themselves. These are images manifested through transformation based on raw substance, and are correct objects of cognition. They are manifested from (älaya) seeds. (2) 獨影境 (C. dúying jing; J. dokuyō kyō) "Image-only objects." Objects manifested from a merely subjective view. These are objects that exist purely in the mind and have no relationship to any raw substance. Illusions are examples of 
the objects of this category, but this can also include objects that appear in meditation, or objects perceived by devas. (3) 帶質境 (C. dàizhi jìng; J. taizetsu kyō) Objects that derive from raw substance but which are not perceived exactly as they are. Despite being grounded in raw sensate appearance, they are, according to the circumstance, not correctly apprehensible, and thus they are the sorts of objects that we call "mistaken," "misconstrued," or “misidentified." See 成唯識 論掌中樞要 $\mathrm{T} 1831.43 .620 \mathrm{a} 20$.

13） The Hae simmil gyeong so 解深密經疏, contained in Hanguk bulgyo jeonseo vol. 1, pp. 123b$478 \mathrm{c} 5$.

14) Although it is difficult to find an explanation of the concepts of bimba-pratibimba in a non-visual trope, interestingly, Dan Lusthaus does use the example of sound to explain the meaning of hyle in Buddhist Phenomenology (Routledge-Curzon, 2002), where he makes the helpful distinction between tone (bimba) and note (pratibimba). (p. 15) However, in the present context of Woncheuk's discussion, we are not talking about music, and not even exactly about "speech," but the "Buddha's teaching." For 本質 in this case, perhaps we can still use tone; for the processed perception, however, it seem that it would be possible that representation could vary in units such as phoneme, word, and phrase.

15）如是四法, 如來自說, 名爲本質. 聞者識變名之爲影. 如是本影有無差別, 總約諸宗, 有其四句. (HBJ1 126b8-10)

16) These are the so-called suffering, emptiness, impermanence, no-self, and the quiescence of nirvāna-because these are cited from the holy teachings.

17) T 664.16.368b10-11. These three are explained by Paramârtha and others as the three periods of the teaching 三時教.

\section{Abbreviations:}

HBJ = Hanguk bulgyo jeonseo. 韓國佛教全書 (The Collected Works of Korean Buddhism) (1984). Seoul: Dongguk University Press. (Electronic Text from Dongguk University used as source)

$\mathbf{T}=$ Taishō shinshū daizōkyō. 大正新脩大藏經 (Japanese Edition of the Buddhist Canon) (192435). Tokyo: Daizō kyōkai. (Electronic Texts from SAT used as source)

〈Key words〉 Woncheuk 圓測, bimba 本質, pratibimba 影像, Kuiji 窺基

(Project Professor, The University of Tokyo) 